\title{
Markets, Networks and the New Welfare State: Employment Assistance Reforms in Australia
}

\section{Mark Considine}

Accepted in Journal of Social Policy (Cambridge, 1999)

\begin{abstract}
Contemporary theoretical debates point to a transformation of societies and social organisations away from universal forms of mass production and consumption, organised through mass institutions, towards smaller, diversified, entrepreneurial units linked together by new forms of market and network co-ordination. This greater diversity is also held to be a feature of service users who require individually fashioned solutions to non-standard problems and tailored products for their different tastes.
\end{abstract}

Applications of these accounts of social and economic transformation to the public sector propose similar patterns to those evident in private industry and in regional communities. The large, standardised bureaucracy is seen to give way to de-coupled, multiple agency models of service delivery within a new type of welfare state.

The study uses interviews and surveys $(n=365)$ with service delivery staff in the Australian employment assistance sector where transformations of this type have recently been sponsored by government. These data indicate that many of the key propositions of the post-Fordist account are valid. Smaller, non-unionised units dominate the new order and services are devolved to the local level. However a number of the expected patterns of flexible specialisation, diversity and networking are not found, suggesting marked differences and possible tensions between public and private sector forms of organisational development in the new order. 


\section{Introduction}

It is now often asserted that the world of large, hierarchically defined public organisations which provide their citizens with a set menu of standard, universal services, delivered by a career workforce, is nearing the end of its time of social and political dominance (Sabel, 1994; Burrows and Loader, 1994; Foster and Plowden, 1996; Considine and Painter, 1997). Government reports, academic research and the soft-back management literature appear to have found rare accord on the fact of this seismic shift, if not on its exact significance.

The new order is far from fully formed, but theorists confidently identify several core characteristics. Organisations will continue to be the primary locus of social and political decision making and play a central role in the delivery of programmes. However they become smaller, are more numerous, and relate to one another through both bureaucratic and non-bureaucratic forms of co-ordination. It is the latter feature which attracts theoretical interest. Diversified forms of service production are seen to reflect principles of flexible specialisation which allow 'net- working between taskspecialist units' (Amin, 1994:20), and promote sector level arrangements in which 'firms, labour interests, officials and politicians can interact and co-operate' (Hirst and Zeitlin, 1991:44).

The models of organisational effectiveness which underpin the post- Fordist literature reflect the contending images of private sector transformation which are projected onto the political screen. As a result it is not always clear whether what is being anticipated is a MacDonalds Welfare State, a clustered regime of 'Silicon Valley' social security agencies, or some unresolved combination of the two (Williamson, 1975; Rogers and Larsen; 1984). Nevertheless, there can be little doubt but that the previous order is in decline and the new world does appear to be centred upon smaller units acting in an entrepreneurial fashion within some de-bureaucratised whole (Drucker, 1985; Powell, 1990; Hoggett, 1987).

In discussions of the state of the welfare state, organisational shifts are seen to run parallel to larger social transformations. These cannot be fully examined here, but two widely discussed issues in the theoretical field do bear directly on the present study. 
The first is that employees in the public sector are viewed as subject to similar pressures to adopt the flexible work patterns evident elsewhere in the economy. Second, the characteristics of clients in the services sector are seen to be changing. As Lash and Urry (1987) point out, greater levels of social diversity in all advanced societies are leading to calls for more varied forms of welfare provision. In other words, the old capital-labour divide, with its '(male) wage earners welfare state' no longer encapsulates the key divisions and tensions in our societies (Offe, 1984).

At the political level this increased diversity and demand for greater flexibility is registered most forcefully as a move towards various forms of 'entrepreneurial governance' (Osborne and Gaebler, 1993) in which states shed large parts of the bureaucratic workforce in favour of smaller local organisations which are linked by markets and networks. There remains a degree of wishful thinking in some accounts of this change: 'Networks of publicly interested discourse which transcend hierarchical institutions provide a feasible model for public administration.' (Fox and Miller, 1995:149)

However, cut down to basic propositions this literature identifies two different dimensions of programme reform - the macro-organisational, and the micro-client levels. They assert changes in the central structures of bureaucracies to be related to forms of devolution to the service delivery level of programmes, together with new elements of client and practitioner empowerment. Clients or customers are thought to be much more a focus of real attention, they are treated as individuals, and previous barriers created by hierarchies and rigidities between hierarchies ('smokestack' and 'pipeline' problems, according to the consultant lexicon) are thought to be reduced or even removed in new service configurations. But we do not know if this means that clients are given the old service in a more reliable manner or a new higher quality service, and if so, which clients these are. And because such accounts of reform also recognise an agenda of budget cutting and productivity saving in the services sector, the relative weight to be given to the competing ideals of better treatments and cheaper service remain unspecified (Niskanen, 1979; Considine, 1994). 
Notwithstanding these uncertainties, when expressed as a form of governance directed at social programmes, the post-Fordist welfare state may be viewed as having a number of central attributes:

- de-coupling of programmes from traditional forms of bureaucratic hierarchy

- decentralisation of key resource allocations

- contracting out of major programme activities

- competition between programme providers

- use of client-centred techniques of co-ordination

- enrollment of clients and their support network into co-produced

- services.

Political scientists have raised a number of questions concerning the multiple agency reforms which are the empirical hallmark of such developments (Mayntz, 1993; Kooiman, 1993). Most important in this field have been questions regarding the extent to which governments can any longer direct or control these diverse systems, the extent to which new steering methods such as re-regulation can include a public interest component, and declining levels of social integration as previously important universal socialising institutions give way to a world of infinite variety (Dunsire, 1986; Mayntz, 1993; Kickert, 1993). In summarising this diverse research literature we may say that the new organisational or system type involves a form of self-organising policy network which has increased scope for entrepreneurial behaviours by officials, and greater discretion in the treatment of clients, but which has not yet been tested in an account of the particular responsibilities and pressures within public programmes.

\section{The rise of case management}

The current forms of system development within contemporary welfare states which expresses these ideas are most easily recognised empirically. They involve greater use of local operational discretion by bureaucrats, the use of purchaser-provider agreements, the development of quasi- markets, and the widespread embrace of forms of deregulation (Le Grand and Bartlett, 1993). Case management in welfare programmes and co- ordinated care in the health sector demonstrate the power of such ideas. 
Case management, or care management, as it is termed in the 1991 protocols developed by the US Department of Health, seeks to place an empowered local official at the crossroads of various practitioner inter- actions. In the Business Process Reengineering lexicon this agent would be known as the process manager or advocate. This official takes responsibility for linking all relevant services together in a single strategy for meeting the needs of an individual client. To do this effectively, the case manager is seen to use a new form of authority to broker deals with separate agencies which previously dealt with the client as part of a standardised service. As Austin (1993:452) argues, the case management model is viewed as an explicit response to the cost and dysfunction of delivery systems which had been structured 'to accommodate providers, funders, and professionals rather than clients.'

In the most developed of these models the case manager has authority for the procurement of the services deemed most useful for the individual client, combining the skills of 'counsellor, salesperson and accountant' (Kemp, 1981, p. 10; Hammond, 1997, p. 34). Where such a role includes responsibility for the assessment of client needs, together with the purchase of services from supplier organisations, the potential for both improved service for the client and greater cost effectiveness are thought to be realised. The enrolment of clients in the new system involves far more than simply appointing internal bureaucratic advocates to work on their behalf.

The 'co-responsibility' and self-governance elements of these reforms also involve greater demands upon clients and their families to contribute extra effort, reduce their use of social assistance, adopt compliant behaviours and meet raised expectations concerning life style change (Rose, 1996). It is also at this point that an organisational transformation away from Fordist ideals of universal consumption towards greater individuality of services and a focus upon co-responsibility is evident (Brudney and England, 1983). In other words, the new model promises an interesting new form of 'governance at ground level' in which clients are called upon to help produce their own programme effects, rather than being consumers of pre-existing, or 'finished' services. As Hasenfeld and Weaver (1996, p. 236) have pointed out, this mix of both intensive support and increased obligation creates 'unique organisational pressures' on clients 
and staff in these programmes and organisational factors dominate evaluations of success and failure.

\section{Research design}

In order to investigate the impact of these changes to welfare provision, this study examines the employment assistance reforms undertaken in Australia between 1994 and 1996. The findings are based upon survey and interview studies completed in 1995-96. Details of sampling and interview selection are included in the endnote below. ${ }^{1}$ For the purpose of the study, the defining characteristics of post-Fordist change were reduced to two hypothesised dimensions. First, that the field be one which was transformed at the macro level of the organisation of the various welfare institutions. This was defined as a shift from the dominance of traditional bureaucracy to one characterised by empowered local officials acting within multiple agency systems and/or quasi-markets. The second condition was defined as the micro transformation of work within this field from a service system based upon rules, procedures and universal categories of entitlement, to one emphasising entrepreneurial and discretionary treatments for individual clients exercised at a local level of programme definition.

The study therefore sought to answer two questions: (1) Are new forms of 'governance at ground level' really any different to the standard bureaucractic model of servicing clients? (2) Does the use of a multiple agency system increase diversity, flexibility or any other desired attribute? The key issues likely to indicate whether or not the system had changed in any of these directions were deemed to include:

- $\quad$ outcome performance of public and private agencies

- caseload differences and effects

- patterns of client and employer contact by local officials

- supervision and discretion

- disciplining of clients

- unionisation and networking

- use of incentives to motivate agencies. 


\section{Background to the Australian programme}

The Australian White Paper, Working Nation (Keating, 1994) issued by the federal Labor government initiated major changes to the national system of labour market assistance available for those unemployed for one year or more. The central initiative in the reform was the government's Jobs Compact which guaranteed that job seekers on benefits for 18 months or more would be given access to either employment of training or both. This was to be provided by case managers in both the public and private sectors. This system of competitive provision of assistance was defined in the Australian White Paper as a part of a new client focus:

The emphasis will move away from processing large numbers of job seekers through relatively rigid national programs. The key elements of the new strategy are an accurate assessment of the needs of job seekers and an intensive plan to assist disadvantaged people. (Keating, 1994: 127)

The key to the delivery of this approach was stipulated as the harnessing of the private welfare and for-profit sectors - 'Healthy competition will lead to service improvement' (Keating, p. 127). In other words the existing government service would be restructured to create a competitive market for the servicing of the long term unemployed.

Not only did the government view this as an appropriate model for delivering services to the most vulnerable sectors of the labour market, but policy makers also made it clear that this was an experiment in competitive welfare provision which might soon be extended to other parts of the federal social security system. The new approach is also frequently contrasted with the weaknesses of the old welfare state with its 'universal provision of a highly standardised and centrally controlled group of services', said to result in a 'traditional one-size-fits-all approach to service delivery'. ${ }^{2}$

The new framework was established as follows; the Department of Employment, Education and Training (DEET) would continue to manage the system but its own Commonwealth Employment Service (CES) would lose its universal service role. A new public agency called Employment Assistance Australia (EAA) would deliver the public sector part of the new market and the Employment Services Regulatory Authority 
(ESRA), the regulator, would license several hundred private providers to compete with EAA. ${ }^{3}$ Up to one third of the 'market' would be transferred to private operators through a tender process administered by ESRA.

To establish a common system of service delivery the government initiated case management as the new methodology to be used by all providers. ESRA would license each provider to tender for a given number of clients, each classified according to their 'degree of difficulty'. For their part the clients would be entitled to select the case management agency they wished to work with, would then be obliged to enter into a formal, signed, Case Management Activity Agreement (CMAA) with this agency, and would attend all interviews, and courses and undertake all other activities deemed to be helpful. All case managers were also authorised to recommend that the client have his or her social security payment suspended or terminated for any non-compliance with the case management process.

Private agents were paid a fee per client composed of an up-front amount to begin the case management process and then half or more of the fee when the client obtained work or was approved for training and completed thirteen weeks of either. Within the public agency, interviews confirm that staff were also made aware of their own success rates, but were more likely to receive this as an office-wide statistic and as comparisons of their office with other public offices state-wide, and compared to private agencies in their region.

The non-profit sector approached the new order with some alarm. For example the Catholic agencies warned that 'people who are long term unemployed must not be forced into inappropriate labour market pro-grams, or job placements'. Their leadership also expressed the view that devolving the responsibility for 'breaching' clients 'is highly problematic' and that case management 'should not have any policing component in it'.4 They and other community service providers indicated that they would seek to establish a network of service deliverers who would co- operate rather than compete with one another. 
Evaluations of the performance of the new system after eighteen months indicated that the government provider performed better than the private agencies, (23.7 per cent of jobseekers successfully placed versus 17.5 per cent placed) but that the latter tended to get better as they gained experience. It also concluded that competition between private agencies increased significantly in the second of the two tender rounds conducted by ESRA (DEETYA, 1996, p. 33). Evaluators also concluded that 'most progress appears to have been made in providing jobseekers with a more personalised service' (DEETYA, 1996, p. 35), the latter reflecting client survey results as well as reports from staff in these agencies. The evaluation also pointed out that government officials were more likely to emphasise compliance issues than were private case man- agers, but no comment was made on the possible differences between firms and community agencies. Later figures also indicate that in the distribution of performance scores the public agency was more likely to deliver average to good service and private agencies were more likely to be found among the very high and very low performers. 
Fig. 1: A model of employment-related case management in Australia 1997.

(Goal: Eligible jobseekers achieve sustainable employment through individual, active, planned and evaluated case management services, provided openly and collaboratively by case managers freely chosen by the jobseekers.)

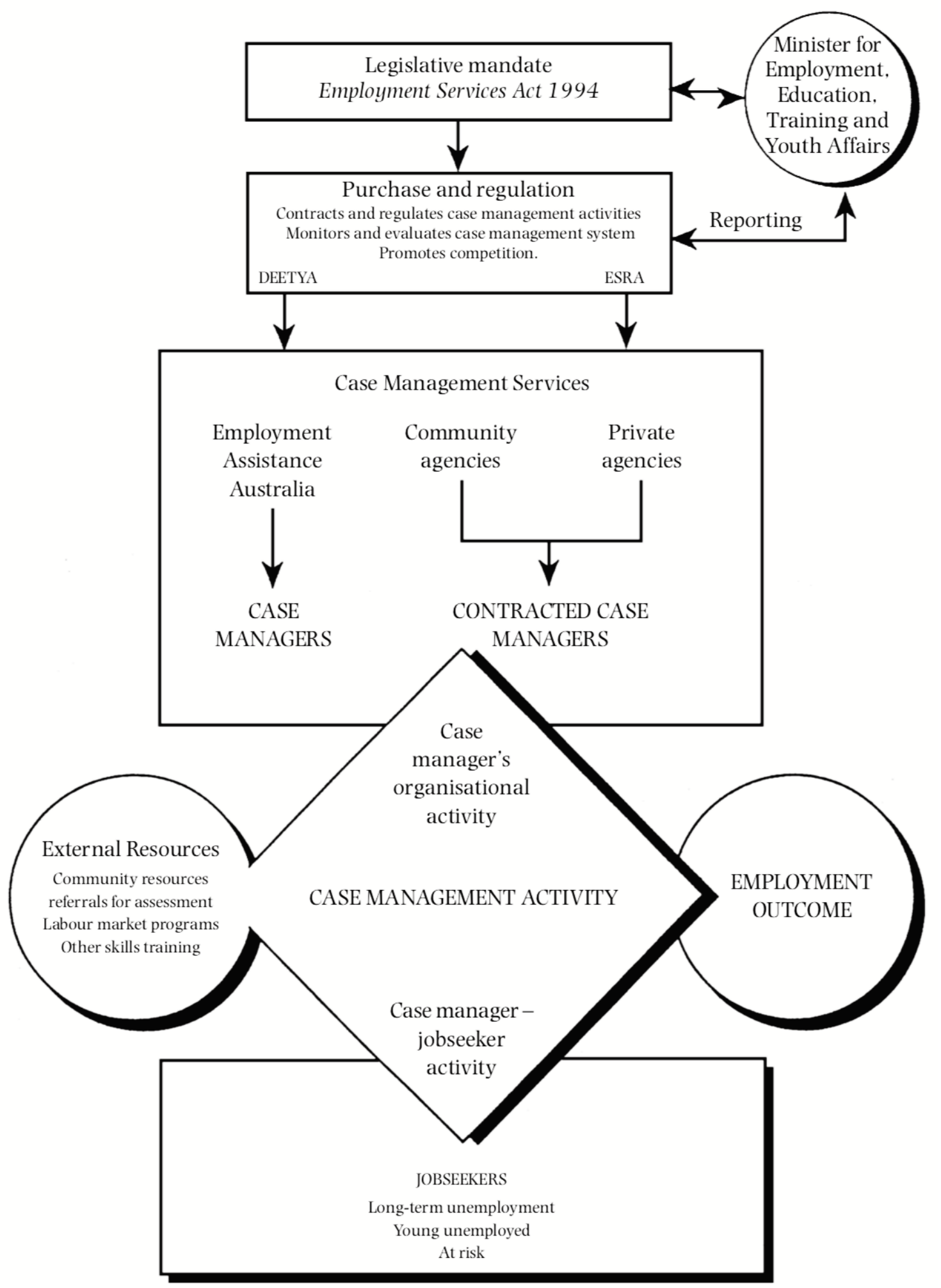




\section{Findings}

The results of the surveys and interviews confirm significant changes in this employment assistance sector and significant differences between participating organisations. The new system does indeed produce a number of the attributes identified by the post-Fordist literature including: many more participating organisations, smaller sized organisational units, flexible, entrepreneurial workplaces, and greater individualisation of services. Not evident were new forms of service networking and flexible specialisation, with new agencies replicating a similar menu of services. All statistics presented are significant at the 0.05 level.

\section{(1) Entrepreneurial work}

A telling indicator of the decisive nature of the shift from the previous bureaucratic workplace to the new post-Fordist style system is the fact that employment itself is seen to become more entrepreneurial, less routinised and less bound by management-union agreements or institutions. The first clear indicator of the direction of system change is demonstrated by the evident differences between a unionised public sector and a new private realm marked by the rise of non-union labour (Table 1). Three quarters of the established government sector were found to be unionised but only 21 per cent of firms and 13 per cent of community agencies were unionised $(r=0.4955)$.

The new sector as a whole also shows a higher level of flexibility at the service level. Case managers said they were 'free to decide' on a day-to- day basis 'what I will do with each client' (82 per cent). Only 16 per cent said that the information technology system used to track clients and interventions 'tell us what steps to take and when to take them'. Most staff (88 per cent) also agreed with the statement 'I like to keep my own records and files on clients and programs.'

However, there was no indication that these officials were now acting without direct supervision. Almost 60 per cent disagreed with the statement 'my supervisor does not know very much about the work I do day-to-day'. These descriptive statistics provide evidence of some notable shifts away from the routinised work of the bureaucratic type and a proliferation of more discretionary styles, albeit within a supervised local management system. This might be termed supervised flexibility. 
Table 1: Unionisation by organisation type

\begin{tabular}{|l|l|l|l|}
\hline $\begin{array}{l}\text { Count } \\
\text { Row Pct }\end{array}$ & & & \\
Tot Pct & Yes & No & Row total \\
\hline Government & 102 & 31 & 133 \\
& 76.7 & 23.3 & \\
& 29.3 & 8.9 & 38.2 \\
\hline Community & 12 & 78 & 90 \\
& 13.3 & 86.7 & \\
& 3.4 & 22.4 & 25.8 \\
\hline Firms & 26 & 99 & 125 \\
& 20.8 & 79.2 & 35.9 \\
\hline Column total & 7.5 & 28.4 & 348 \\
& 140 & 208 & 100.0 \\
\hline
\end{tabular}

In interviews and observation visits to offices, these officials elaborate a pattern of service decentralisation and a reduction in the scale of operations. Typically the officials from public employment offices work in a local office which is smaller and more focused than the previous CES structure. Average sized EAA offices were twelve to fifteen staff, compared with CES offices of fifty or more staff. Private officials worked in even smaller offices, often employing only three or four staff. Furthermore, all these staff work on a more limited range of activities for a defined number of clients. They typically do not provide benefit delivery, training or registration services and do not have employer support roles. Instead they work with their own client list and manage their own time allocations to these clients.

\section{(2) Differences between agencies}

The second important set of distinctions concern the detailed effects of involving forprofit (firms) and non-profit (community) organisations alongside a public agency in a competitive system. The factors expected to distinguish the three types (public agency, firms and community agencies) were degree of supervision, amount of discretion, attitude to clients, competitiveness and approach to the use of sanctions. 
The degree of supervision did vary significantly between organisation types. While the government officials did register comparatively high levels of supervision, with 50 per cent agreeing that they referred difficult cases to a supervisor, the highest ranking (61 per cent) went to community agencies. Firms ranked lowest in their degree of supervision (41 per cent). When asked if their supervisor knew a great deal about the work they did 'day-to-day', community agencies again ranked highest with 71 per cent agreement and the other two types approximately equal at 51 per cent. Reliability analysis also confirmed that the four items used to test levels of supervision were highly consistent (alpha $=0.8817)$.

Table 2: 'I refer difficult cases to my supervisor' by organisation type

\begin{tabular}{|l|l|l|l|l|l|l|}
\hline $\begin{array}{l}\text { Count } \\
\text { Row Pct } \\
\text { Tot Pct }\end{array}$ & $\begin{array}{l}\text { Strongly } \\
\text { disagree }\end{array}$ & Disagree & Neither & Agree & $\begin{array}{c}\text { Strongly } \\
\text { agree }\end{array}$ & Row total \\
\hline Government & 10 & 30 & 27 & 56 & 11 & 134 \\
& 7.5 & 22.4 & 20.1 & 41.8 & 8.2 & \\
& 2.9 & 8.6 & 7.7 & 16.0 & 3.2 & 38.4 \\
\hline Community & 5 & 15 & 15 & 48 & 8 & 91 \\
& 5.5 & 16.5 & 16.5 & 52.7 & 8.8 & \\
& 1.4 & 4.3 & 4.3 & 13.8 & 2.3 & 26.1 \\
\hline Firms & 18 & 38 & 17 & 44 & 7 & 124 \\
& 14.5 & 30.6 & 14.7 & 35.5 & 5.6 & \\
& 5.2 & 10.9 & 4.9 & 12.6 & 2.0 & 35.6 \\
\hline Column & 33 & 83 & 59 & 148 & 26 & 349 \\
total & 9.5 & 23.8 & 16.9 & 42.4 & 7.4 & 100.0 \\
\hline
\end{tabular}

There are two major areas of work in which case managers might exercise significant levels of discretion. The first concerns drawing up binding agreements with clients in regard to the kinds of activities they must undertake. Legislation requires that all clients have such an agreement in place during the whole time they are undergoing case management. Officials may propose various mixtures of work experience, training, counselling and job search tasks in each case. Interviews and focus groups indicated that organisations varied in the extent to which standard formulae were to be used by 
all officials at a given site, thereby reducing variations available to individual staff members and re-bureaucratising this work. Those most likely to say that their 'own judgement' was very important in determining the content of agreements were private firms (75 per cent). The significant results for the other two types showed agreement at 55 per cent.

The disciplinary aspects of the new system also impacted differently according to organisational type. Welfare rights groups pointed out that the new system placed greater pressure on beneficiaries and Finn (1997, p. 41), reporting on behalf of an advocacy organisation, concluded that the 'new penalty regime was being more generally enforced.' The vast majority of those cited for breaches were not penalised, however. Many sanction recommendations for minor infringements were later withdrawn or overturned. But, at the other end of the scale, repeat offenders received harsher, cumulative penalties.

The study asked case managers to estimate the number of clients they had sanctioned in the previous two months. These results were coded into 'low', 'medium' and 'high' using three equal distributions from the frequency scores. Low scores were two or three clients in a two month period, high scores were twelve and above. Contrary to the expected image of the community sector as the least interested in the application of these regulations, this sector scored higher than did private firms. However, the rating for government officials was clearly higher than either of the other sectors.

This pattern was consistent with the findings of the government's own evaluation of the first eighteen months of the new system. Interviews confirm that compliance with case management activities is viewed as a key objective by all officials. Rather than use official sanctions, however, the private agencies prefer to issue strong cautions, threats and positive reinforcement of their roles as social security agents. A number of private agencies also use the computer classification 'no longer requires assistance' to cut clients off benefits without a formal sanction. This allows them to manage the compliance issue in-house and without the difficulties associated with semi-judicial sanctions and appeals. 
In interviews these officials explained their attitudes to the different use made of disciplinary tools. Government officials were least likely to regard the client's reaction to being sanctioned as a reason to vary their own response to rule breaking. Private agencies were more likely to say that they believed their reputation with clients and other organisations (including the central government office responsible for allocating clients and filling programmes) might suffer if they used the disciplinary powers available to them. Reputation played a significant role in such judgements and may be regarded as an important variable in quasi-markets.

The least predictable responses came from agencies with a philanthropic or welfare history. Not only do community agencies demonstrate higher sanctioning and supervision rates than expected, they are also significantly less likely to define themselves as advocates of client rights. Qualitative data, including interviews and statements by industry leaders, point to a significant tension between the role of nonprofit organisations in protecting clients from invasive demands by new government programmes and their new roles as small businesses seeking to earn income from assisting job seekers.

Table 3: Sanctioning rates by organisation type

\begin{tabular}{|l|l|l|l|l|}
\hline $\begin{array}{l}\text { Count } \\
\text { Row Pct } \\
\text { Tot Pct }\end{array}$ & \multicolumn{1}{|c|}{ Low } & \multicolumn{1}{|c|}{ Medium } & \multicolumn{1}{c|}{ High } & \multicolumn{1}{|c|}{ Row total } \\
\hline Government & 34 & 65 & 26 & 125 \\
& 27.2 & 52.0 & 20.8 & \\
& 12.1 & 23.0 & 9.2 & 44.3 \\
\hline Community & 31 & 30 & 11 & 72 \\
& 43.1 & 41.7 & 15.3 & \\
& 11.0 & 10.6 & 3.9 & 25.5 \\
\hline Firms & 44 & 31 & 10 & 85 \\
& 51.8 & 36.5 & 11.8 & 30.1 \\
\hline Column total & 15.6 & 11.0 & 3.5 & 282 \\
& 109 & 126 & 47 & 100.0 \\
\hline
\end{tabular}


It was expected that this group would score highest on measures of advocacy. The latter is extremely difficult to measure and these results must be approached with caution. Respondents were asked to respond to the statement. 'I consider myself to be an advocate for the client's rights and interests'(Table 4). Being framed in this socially desirable form, interest lies in the degree of positive response and differences between agencies. Firms rate highest followed by government officials. Community agencies are significantly less comfortable with this as a description of their roles.

Finally, it was expected that private firms would be significantly more attuned to the competitive aspects of the new system. This part of the reformed sector was expected to emerge in relation to the extent to which case managers organise their interventions around those clients most likely to produce payable outcomes. In addition, it was expected that those working in firms would be more subject to management systems designed to record and evaluate individual financial performance. The four competition-incentive variables were also subjected to reliability analysis to show consistency between related items (alpha $=0.5780$ ).

Significant but minor differences were found between organisations in responses to the statement 'I always divide my clients into those that will generate a payable outcome on my efforts, and those that probably will not.' Most of the sample disagreed with this and there were no major differences between the three types.

Table 4: 'I see myself as a client advocate' by organisation type

\begin{tabular}{|c|c|c|c|}
\hline $\begin{array}{l}\text { Count } \\
\text { Row Pct } \\
\text { Tot Pct }\end{array}$ & Yes & No & Row total \\
\hline Government & $\begin{array}{l}105 \\
80.2 \\
30.9\end{array}$ & $\begin{array}{l}26 \\
19.8 \\
7.6\end{array}$ & $\begin{array}{l}131 \\
38.5\end{array}$ \\
\hline Community & $\begin{array}{l}61 \\
70.1 \\
17.9\end{array}$ & $\begin{array}{l}26 \\
29.9 \\
7.6\end{array}$ & $\begin{array}{l}87 \\
25.5\end{array}$ \\
\hline Firms & $\begin{array}{l}102 \\
83.6 \\
30.0\end{array}$ & $\begin{array}{l}20 \\
16.4 \\
5.9\end{array}$ & $\begin{array}{l}122 \\
35.9\end{array}$ \\
\hline
\end{tabular}




\begin{tabular}{|l|l|l|l|}
\hline Column total & 268 & 72 & 340 \\
& 78.8 & 21.2 & 100.0 \\
\hline
\end{tabular}

Despite this apparent reluctance to admit streaming or creaming clients according to profitability, when asked if their organisations 'pay attention to the income I generate', important differences emerged. As expected both private types were strongly in agreement with this statement and firms rated this far higher than either other type (Table 5). A third question asking whether the objective of this work was to get the 'highest number of payable outcomes' showed community organisations to be more aware of this task than either of the other two groups. These data suggest that while case managers from firms are prepared to acknowledge the competitive motives of their employing organisations, community officials see this as an attribute of the total system but do not necessarily experience this as a local attribute of their own practice.

Table 5: 'My organisation pays attention to the income I generate' by organisation type

\begin{tabular}{|l|l|l|l|l|l|l|}
\hline $\begin{array}{l}\text { Count } \\
\text { Row Pct } \\
\text { Tot Pct }\end{array}$ & $\begin{array}{l}\text { Strongly } \\
\text { disagree }\end{array}$ & Disagree & Neither & Agree & $\begin{array}{l}\text { Strongly } \\
\text { agree }\end{array}$ & Row total \\
\hline Government & 28 & 34 & 37 & 29 & 3 & 131 \\
& 21.4 & 26.0 & 28.2 & 22.1 & 2.3 & \\
& 8.1 & 9.9 & 10.7 & 8.4 & 0.9 & 38.0 \\
\hline Community & & 3 & 9 & 61 & 18 & 91 \\
& & 3.3 & 9.9 & 67.0 & 19.8 & \\
& 1 & 0.9 & 2.6 & 17.7 & 5.2 & 26.4 \\
\hline Firms & 0.8 & 3 & 4 & 79 & 36 & 123 \\
& 0.3 & 0.9 & 1.2 & 22.9 & 10.4 & 35.7 \\
\hline Column & 29 & 40 & 50 & 169 & 57 & 345 \\
total & 8.4 & 11.6 & 14.5 & 49.0 & 16.5 & 100.0 \\
\hline
\end{tabular}




\section{(3) Patterns in building relationships}

A defining condition of post-Fordist welfare organisations is deemed to be a change towards greater networking in the pattern of relationships with welfare clients, with other organisations in the sector and with the major opportunity providers - in this case employers and government agencies. This is certainly consistent with government initiatives to promote net- working among employment agencies. ${ }^{5}$

Interviewees and survey respondents were asked a series of questions about the way they divide their time. The means for time spent with job seekers, other providers, employers and on general administration were 52 per cent, 10 per cent, 11 per cent and 25 per cent. In other words the bulk of case management was concerned with seeing clients and doing clerical work. Significant differences were found in relation to time spent with employers. Despite the expected natural affinity between firms and employers, theirs was not the highest reported rate of contact. Community agencies worked hardest on this item with 20 per cent reporting very high levels of contact against an average of 7 per cent for the two other types.

In interviews it was revealed that community agencies devoted considerably more time to assisting clients with securing interviews with prospective employers. Firms on the other hand often said that they did not arrange interviews but concentrated their limited employer contact time on promotional work. A number of the private agents also reported that their organisations had other services such as training available for employers and it is likely that the contact item reflected this non-client specific activity.

A strong significant relationship existed between agency type and likelihood of providing ancillary services such as labour market training, work experience and work placement services. Private firms excel at this level, providing them with a sizable advantage (Table 6). Some 87 per cent of firms possess other in-house services involving employment services, many of which involve subsidies and discount opportunities for employers. 
Table 6. 'Does your organisation provide other employment services?' by organisation type

\begin{tabular}{|c|c|c|c|}
\hline $\begin{array}{l}\text { Count } \\
\text { Row Pct } \\
\text { Tot Pct }\end{array}$ & Yes & No & Row total \\
\hline Government & $\begin{array}{l}88 \\
65.7 \\
25.3\end{array}$ & $\begin{array}{l}46 \\
34.3 \\
13.2\end{array}$ & $\begin{array}{l}134 \\
38.5\end{array}$ \\
\hline Community & $\begin{array}{l}51 \\
56.0 \\
14.7\end{array}$ & $\begin{array}{l}40 \\
44.0 \\
11.5\end{array}$ & $\begin{array}{l}91 \\
26.2\end{array}$ \\
\hline Firms & $\begin{array}{l}108 \\
87.8 \\
31.0\end{array}$ & $\begin{array}{l}15 \\
12.2 \\
4.3\end{array}$ & $\begin{array}{l}123 \\
35.3\end{array}$ \\
\hline Column total & $\begin{array}{l}247 \\
71.0\end{array}$ & $\begin{array}{l}101 \\
29.0\end{array}$ & $\begin{array}{l}348 \\
100.0\end{array}$ \\
\hline
\end{tabular}

Different agency patterns also emerged in relation to frequency of contact by case managers with employers, government departments, local government, other case management agencies, schools and universities, local service clubs (Lions, Rotary, etc.) and the media. These indicators of 'network effectiveness' were subjected to reliability analysis and proved consistent (alpha $=0.7535$ ). Government agencies had higher contact with other government agencies, welfare officials registered highest with all other types of outside organisation. Firms recorded lower frequency of contact with all categories of outside groups.

Finally, all job seeker contact items were scaled and showed high levels of reliability (alpha $=0.7911)$. All these items showed significant differences by organisational type. Most interesting were differences between government and non-government agencies where large differences in levels of daily and weekly (i.e., high) contact with job seekers were evident among non-government agencies. Community agencies recorded slightly higher contact rates with clients than did firms.

The level of job seeker contact was also compared with loads using a number of classifications. Significant findings were evident only for very high loads. Only when load exceeds 120 clients per case manager does rate of contact with clients vary. Up to 
this point load is not a significant factor. However, the likelihood of having high caseloads is strongly associated with being a government provider $(r=0.4439)$ where 59 per cent have loads over 120 clients compared with 41 per cent of private agencies. This suggests that load factors act to widen the distance already evident among agency types.

\section{Discussion}

A number of important aspects of the post-Fordist era appear to be confirmed by the study. All officials record higher levels of discretion in relation to clients than expected from traditional universal systems of registration and referral. Programme rules, including the definition of case management, actively support this pattern. Traditional reliance upon standard methods for processing clients was not found and all three types of organisation demonstrated strong forms of individualised treatment.

Also significant was the shift away from unionisation, particularly in the nongovernment sector, further reinforcing the pattern of workplace transformation. Interviews with policy makers in central agencies gave some insight into the importance of this attribute. According to one Department of Finance official, 'the most important element of the new system as far as we are concerned is change in the labour market ... Not the labour market for the unemployed, but in the public sector labour market.' In other words the use of quasi-markets are one important response to perceived failures in getting public sector managers and unions to address productivity deficits in the public service environment (Foster and Plowden, 1996: 7).

The new system has also supported the rise of smaller workplaces and the proliferation of an increased number of service delivery sites and types. Private agencies have significantly fewer employees and, in the case of firms, do not lack a wide range of service options. Indeed the private firms have a significantly wider menu of services available for employers and clients than do either of the other sectors. However this reduced scale of operation is not associated with any major decline in supervision. Discretion over clients does not amount to a freedom from direct supervision in the manner of the professional workforce. Nor do such agencies seek to employ staff with 
professional qualifications. Instead officials are recruited from the clerical ranks and from university graduates with a wide range of backgrounds. Work proceeds as part of a regulated and supervised system of local obligations and objectives.

Community agencies show an unexpectedly high level of supervision. While this data do not allow us to distinguish between collaborative and hierarchical forms of supervision, it is clear that community agencies constitute a distinctive type. At the very least, their high reliance upon supervisor input suggests more complexity in decision making than in either of the other sectors, perhaps indicating their greater ambivalence in regard to their new small business functions, an ambivalence not shared by the government official or the for-profit operator.

More difficult to reconcile with standard interpretations of agency philosophies and stated goals is the community agency's higher use of sanctioning. Firms might have been expected to be tougher. Again it appears likely that each type of agency possesses unique problems in regard to management of their reputations among clients, employers and policy makers. Public officials work in larger offices where 'reputation' effects are less obvious. They also have strong obligations to honour a variety of other government policies which effect employment assistance. This helps explain the higher rates of sanctioning by government agencies. Community agencies, on the other hand, may have a longer history with disadvantaged clients than firms and may therefore feel less at risk from a reputation for tough standards. Because employers and policy makers expect community agencies to be softer on clients there may also be a perverse incentive for them to 'prove themselves' through higher rates of sanctioning. This was partly confirmed in interviews.

This also helps explain why community agencies score lower than expected on the measure for client advocacy. This is not an attribute which they feel will gain them a durable share of the new market. This is reinforced by the finding that community organisations are the type most aware of the system imperatives for income generation. To date, government officials have had a budget system which allows them to retain most independence from these pressures and have therefore continued to treat larger numbers of clients on the basis of their statutory obligations. 
The inter-organisational characteristics of the three types also suggest strongly that private firms occupy an advantageous position in quasi-markets of this type. They appear to have to spend less time on clients and on contacting employers than other groups, and are more able to rely upon an existing structure of services and relationships than upon cold- canvassing of employers and other individual representations on behalf of their clients. The findings suggest that while post-Fordist forms of service delivery are strongly evident at both the macro-organisational and the micro-service levels, inconsistencies persist.

Government retains a strong hand in this system and this 'purchasing' role establishes it as the primary customer in all transactions. Client choice appears to be minimal and new compliance requirements actually reduce job seeker discretion. Market incentives dominate virtually all transactions in the private sectors but they impact very differently upon each type of organisation. Undercapitalised community agencies appear most vulnerable and respond by seeking to maintain non-selective work patterns and more universal treatments. Firms are the most strategic in their behaviours. They focus upon selected clients and limit other trans- actions. Their lower rates of sanctioning may reflect the fact that this activity is time consuming, has reputation risks, and does not generate income.

Networking across organisations is minimal and agencies are deeply suspicious of one another's motives. Government officials attend most meetings overall, but community agencies put greatest effort into external, non-government contacts. Firms mostly network internally, relying upon in-house collaborations inside a multidimensional employment service. Government case managers have the best overall performance, are the most reliable, and are the most likely to try to implement more difficult policy objectives such as sanctioning and care for special populations. But they also lack the organisational resources to promote them- selves as independent players in the new entrepreneurial order. As a result their role continues to be redefined and limited by new government reforms aimed at further enhancing the private role in this system. ${ }^{6}$ 
Notes

1. Interview study: Case manager structured interviews $(n=41)$ conducted in $1995 / 6$ and

composed three sites from each of the three ownership types. Two focus groups ( $\mathrm{n}=$ 25) with public officials were conducted in 1996.

Survey instrument and sampling

Public case managers were surveyed at a national training programme in July 1996.

Attendees came from all parts of Australia, were selected on the basis of self-

nomination and then approval by management. A 67 per cent response rate was achieved. No observed differences between respondents and non-respondents were identified. To test for response bias the answers to client contact questions were compared to similar questions used in interviews and focus groups. No major differences were detected.

In September 1996 the same survey was mailed to approximately half the registered private providers determined by random assignment. Following one round of telephone call-backs a response rate of 73 per cent was achieved. No significant differences were observed between respondents and non-respondents in regard to sex, seniority or organisation type. The organisational profile of the Australian sample was thus as follows:

\begin{tabular}{|l|l|l|}
\hline & No. & $\%$ \\
\hline Public & 135 & 37 \\
\hline Community & 92 & 25 \\
\hline Firms & 127 & 35 \\
\hline Missing & 11 & 3 \\
\hline & 365 & 100 \\
\hline
\end{tabular}

2. Chris Robinson, assistant secretary, Department of Prime Minister and Cabinet, Employment Case Management and Public Sector Reform, 10 July 1995.

3. ESRA (1997) Partnership for Work: The Challenge of Competition in Case Management, Melbourne. 
4. Fr. David Cappo, national director, Australian Catholic Social Welfare Commission, 'Our values and our skills: an ideal combination for case management', National Summit on Employment Opportunities and Case Management, Parkroyal Plaza Hotal, Sydney, 14-15 March 1995.

5. ESRA (1997) sought to emphasise the 'partnership' objectives of the new system through the development of local case management network meetings in all regions.

6. After its election in 1996, the new coalition government announced a further restructure in which the public employment service would be split in two. One part would move to a new social security 'one-stop-shop' and the other half would become a more independent public employment placement enterprise (PEPE). Most of the Working Nation training programmes were abolished and the new tender offers to pay agencies only for job placements which endure for 26 weeks. 


\section{References}

A. Amin (1994), Post-Fordism: A Reader, Blackwell, Oxford.

C. D. Austin (1993), 'Developing case management: a systems perspective', Journal of Contemporary Human Services, October, 451-9.

J. Brudney and R. England (1983), 'Toward a definition of the coproduction concept', Public Administration Review, 43: 1, 23-3.

R. Burrows and Brian Loader (eds.) (1994), Towards a Post-Fordist Welfare State?, Routledge, London.

M. Considine (1994), Public Policy: A Critical Approach, Macmillan, Melbourne.

M. Considine and Martin Painter (eds.) (1997) Managerialism: The Great Debate, University of Melbourne Press, Melbourne.

Department of Education and Employment and Youth Affairs (DEETYA) Australia (1996), Working Nation: Evaluation of the Employment, Education and Training Elements, Evaluation and Monitoring Branch, Canberra.

P. Drucker (1985), The Executive in Action, HarperBusiness, New York.

A. Dunsire (1986), 'A cybernetic view of guidance, control and evaluation in the public sector', in F. Z. Kaufman, J. Majone and V. Ostrom (eds.), Guidance, Control and Evaluation in the Public Sector, New York, De Gruyter.

D. Finn (1997), Working Nation: Welfare Reform and the Australian Jobs Compact for the Long Term Unemployed, Australian Council of Social Services, Darlinghurst, NSW.

C. Foster and Francis Plowden (1996), The State Under Stress: Can the Hollow State Be Good Government?, Open University Press, Buckingham.

C. Fox and Hugh T. Miller (1995), Postmodern Public Administration: Towards Discourse, Sage, Thousand Oaks, CA.

Government of Australia, (1994), Working Nation: Policies and Programs, Government White Paper, Australian Government Publishing Service, Canberra.

B. Hammond (1997), Foundations of Case Management, Deakin University, Australia.

Y. Hasenfeld and Dale Weaver (1996), 'Enforcement, compliance, and disputes in welfare-to-work programs', Social Service Review, June, 235-56.

P. Hirst and J. Zeitlin (1991), 'Flexible specialisation versus post-Fordism: theory, evidence and policy implications', Economy and Society, 20: 1, 1-56.

P. Hoggett (1987), 'A farewell to mass production? Decentralisation as an emergent private and public sector paradigm', in P. Hoggett and R. Hambelton (eds.), Decentralisation and Democracy, Occasional Paper 28, School for Advanced Urban Studies, University of Bristol. 
P. Keating (1994), Working Nation: The White Paper on Employment and Growth, Australian Government Publishing Service.

B. J. Kemp (1981), Annual Review of Rehabilitation, vol II, Springer, New York.

W. Kickert (1993), 'Complexity, governance and dynamics: conceptual explorations of public network management', in Jan Kooiman (ed.) Modern Governance: New Government Society Interactions, Sage, London.

J. Kooiman (ed.) (1993), Modern Governance: New Government-Society Interactions, Sage, London.

S. Lash and J. Urry (1987), The End of Organised Capitalism, Polity, Cambridge.

J. Le Grand and W. Bartlett (eds.) (1993), Quasi-Markets and Social Policy, Houndmills, Macmillan, London.

R. Mayntz (1993), 'Governing failures and the problems of governability: some comments on a theoretical paradigm', in Jan Kooiman (ed.), Modern Governance: New Government-Society Interactions, Sage, London.

W. A. Niskanen (1979), 'Competition among government agencies', American Behavioural Scientist, 22, 517-24.

C. Offe (1984), 'Arbeitsgesellschaft', Sturkurprobleme und Zundunftsperpectiven, Campus, Frankfurt.

E. Olin Wright (ed.) (1995), Associations and Democracy, Verso, London.

D. Osborne and Ted Gaebler (1993), Reinventing Government: How The Entrepreneurial Spirit is Transforming the Public Sector, Plume, New York.

W. W. Powell (1990), 'Neither market nor hierarchy: network forms of organisation', Research in Organisational Behavior, 12, 295-336.

E. M. Rogers and Judith K. Larsen (1984), Silicon Valley Fever: Growth of High Technology Culture, Basic Books, New York.

N. Rose (1996), 'Governing “advanced” liberal democracies', in Andrew Barry, Thomas Osborne and Nickolas Rose (eds.), Foucault and Political Reason, UCL Press, London.

C. Sabel (1994), 'Flexible specialisation and the re-emergence of regional economies', in P. Hirst and J. Zeitlin (eds.), (1989), Reversing Industrial Decline? Industrial Structure and Policy in Britain and her Competitors, Berg, Oxford, reproduced in Ash Amin (ed.) (1994), Post Fordism: A Reader, Blackwell, Oxford.

0. Williamson (1975), Markets and Hierarchies, New York, Free Press. 